\title{
« Nasîr al-Dîn al-Tûsî on Lunar Crescent Visibility and an Analysis with Modern Altitude-Azimuth Criteria ». Suhayl, 3 (2002 - 2003), pp. 231 - 243.
}

\section{Benno van Dalen}

\section{(2) OpenEdition}

Journals

Édition électronique

URL : http://journals.openedition.org/abstractairanica/2318

ISSN : 1961-960X

Éditeur :

CNRS (UMR 7528 Mondes iraniens et indiens), Éditions de l'IFRI

Édition imprimée

Date de publication : 15 mai 2005

ISSN : 0240-8910

Référence électronique

Benno van Dalen, « « Nasîr al-Dîn al-Tûsî on Lunar Crescent Visibility and an Analysis with Modern Altitude-Azimuth Criteria ». Suhayl, 3 (2002 - 2003), pp. 231 - 243. », Abstracta Iranica [En ligne], Volume 26 | 2005, document 322, mis en ligne le 07 décembre 2005, consulté le 25 septembre 2020. URL : http://journals.openedition.org/abstractairanica/2318

Ce document a été généré automatiquement le 25 septembre 2020.

Tous droits réservés 
« Nasîr al-Dîn al-Tûsî on Lunar Crescent Visibility and an Analysis with Modern Altitude-Azimuth Criteria ». Suhayl, 3 (2002 - 2003), pp. $231-243$.

Benno van Dalen

The author describes the criterion for first visibility of the lunar crescent after New

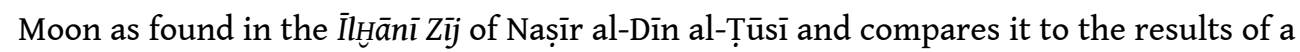
computer program based on a modern criterion for visibility.

\section{INDEX}

Thèmes : 10. Histoire des Sciences et des Techniques nompropre Nașīr al-Dīn al-Ṭūsī, Ṭūsī, Tusi

\section{AUTEURS}

BENNO VAN DALEN

J. W. Goethe-Universität - Frankfurt 